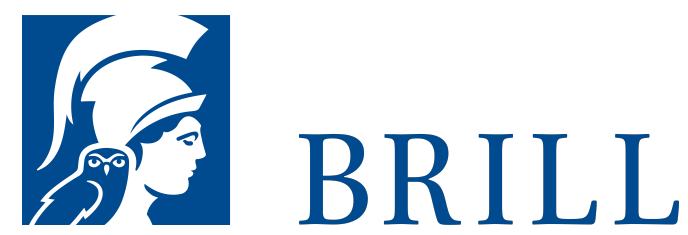

\title{
Die handschriftliche Überlieferung der Gedichte Gregors von Nazianz
}

3. Die epischen und elegischen Gruppen

Authors: Käthe Sicherl and Martin Sicherl

Mit diesem, posthum herausgegebenen Band ist das Fundament für die Rezension aller Gedichtgruppen der direkten Überlieferung gelegt, von denen hier die epischen und elegischen Gruppen rezensiert werden. Darüber hinaus werden Varianten kritisch beurteilt und Verderbnisse konjektural geheilt.

Die Grundstruktur der Gedichte kehrt häufig wieder, unterliegt aber auch Modifizierungen und Erweiterungen. Verschiebungen von Abhängigkeiten und Verästelungen wurde nachgegangen und Abhängigkeiten der Textzeugen neu diskutiert. Damit ergaben sich auch wichtige Erkenntnisse zu ihrer Herkunft. Die Athos-Klöster haben für die Überlieferung offenkundig eine große Bedeutung gehabt.

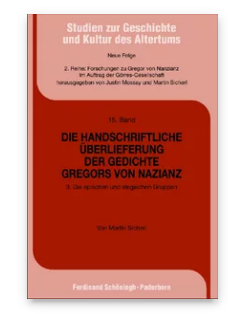

Pages: XVIII + 262 Seiten, 26 s/w Abb.

Language:

German

Subjects:

General,

Literature and

Cultural Studies

Publisher: Brill|

Schöningh

Series:

Studien zur

Geschichte und

Kultur des

Altertums,

Volume: 15

E-Book (PDF)

Released online:

11 Jul 2019

ISBN: 978-3-

657-71755-2

List price

USD \$63.0o

Paperback

Publication date:

16 Feb 2011

ISBN: 978-3-

506-71755-9

List price

USD \$63.00 
For more information see brill.com

Order information: Order online at brill.com +44330 333 0049 | customerservices@brill.com Submission information: brill.com/authors

Titles published by Brill | Fink, Brill | mentis or Brill | Schöningh: +49(o)715413279216| brill@brocom.de 